\title{
Epidemiologi ved sklerodermi hos barn
}

\author{
Odd Vinje og Berit Flatø \\ Revmatologisk avdeling, Rikshospitalet
}

\section{ENGLISH SUMMARY}

Vinje O, Flatø B. The epidemiology of scleroderma in children. Nor J Epidemiol 2008; 18 (1): 89-92.

Localized scleroderma is an infrequent disease in children, but still ten times more frequent than systemic sclerosis. The incidence is probably $5-10 / 100,000$ per year. The disease is classified into five subgroups. Paediatric rheumatologists report linear scleroderma as the most frequent subgroup whereas plaque morphea is found most frequently by dermatologists, linear scleroderma being in second place. The risk of transforming into systemic sclerosis is minimal. The mortality risk is not found increased compared with the normal population.

Systemic sclerosis is the most infrequent systemic connective tissue disease in children, the incidence is less than $1 / 1,000,000$ per year. The outcome in children is considered to be generally better than in adults. However, deaths is caused most frequently by heart failure with or without pulmonal hypertension, but also by renal or respiratory insuffiency, CNS disease and sepsis. Cumulative survival after 5, 10, 15 and 20 years of disease is reported to be $89 \%, 80 \%, 74 \%$ and $69 \%$. For the age group less than 16 years the median age of death is reported to be 10.4 years, range 5 to 15 years. The disease in the children who die is often rapidly progressing with early involvement of internal organs.

Sklerodermi er en heterogen sykdomsgruppe av ukjent årsak hvor det mest iøynefallende kliniske funn er stram hud. Sykdommen inndeles i 2 hovedgrupper:

- Lokalisert sklerodermi

- Systemisk sklerose

Den dominerende sykdom hos barn og unge er lokalisert sklerodermi som i motsetning til systemisk sklerose nesten aldri angriper indre organer.

\section{A. LOKALISERT SKLERODERMI}

Hovedangrepspunktet er huden, men ved lineær sklerodermi angripes ofte subkutane fascia, muskulatur og ben.

\section{Klassifikasjon}

Den mest brukte klassifikasjon inndeler sykdommen i fem undertyper (1):

- Plaque morfea

- Generalisert morfea

- Bulløs morfea

- Lineær morfea (inklusiv Coup de Sabre)

- Dyp morfea

\section{Plaque morfea}

Den mest benigne form av lokalisert sklerodermi, og i de fleste tilfeller kun lokalisert til dermis.

\section{Generalisert morfea}

Multiple plaques som angriper tre eller flere anatomiske områder eller individuelle plaques som etter hvert blir sammenhengende.

\section{Bulløs morfea}

Opptrer ofte sammen med andre undergrupper og involverer bulløse forandringer.

\section{Linecer morfea}

Det utvikler seg her en eller flere lineært angrepne hudområder/streker i over- eller underekstremiteter, hyppigst underekstremiteter. Lesjonen følger ofte et dermatom i utbredelse og er unilateral i 85-95\%. Den første manifestasjonen er vanligvis et lokalisert område med erythem og voksaktig indurasjon og med en erythematøs halo som gradvis brer seg. I tillegg til huden kan det komme affeksjon av underhud, muskel og underliggende ben. Resultatet blir da hypoplasi av de angrepne områdene med svinn av underhud, muskelatrofi og nedsatt lengdevekst av ben.

De fleste beholder likevel bra muskelstyrke. Mange utvikler anisomeli (benlengdeforskjell) som kan bli opptil flere $\mathrm{cm}$. Den aktive prosessen pågår gjerne i 35 år. I rolig/sen fase vil hudaffeksjonen fremtre mer brunlig, og indurasjonen i hud er blitt mindre eller gått helt tilbake.

En sjelden form for lineær sklerodermi er "Coup de sabre" der hode/ansikt er involvert.

Dyp morfea

Den sjeldneste undertypen, men kan gi nokså uttalte forandringer.

To undersøkelser viser at flere undertyper opptrer sammen i $15 \%$ av tilfellene $(2,3)$.

\section{Insidens}

Usikkert hos barn. Sjelden sykdom, men trolig opptrer lokalisert sklerodermi 10 ganger hyppigere enn systemisk sklerose som man antar opptrer hos $<1 / 1.000 .000$ barn pr. år $(1,4)$. Mens det hos voksne er plaque morfea som er den hyppigste formen er det fra barnerevmatologiske sentere rapportert at lineær sklerodermi er hyppigst hos barn (1). Fra en stor multisenterstudie 
utgått fra en rekke barnerevmatologiske sentre er det rapportert følgende fordeling av ulike undergrupper: Lineær sklerodermi (69\%), plaque morfea (26\%), generalisert morfea (7\%), dyp morfea (2\%), blandet subtype $15 \%(3,5)$. Fra hudavdeling er det imidlertid rapportert at plaque morfea er hyppigste lokaliserte form både hos barn og voksne, henholdsvis $48 \%$ og $65 \%$ av alle med lokalisert sklerodermi (2). Den samme gruppen fant imidlertid at lineær sklerodermi er hyppigere hos barn enn voksne. Woo et al. rapporterer at kun $2 \%$ av henviste pasienter til barnerevmatologisk senter hadde lokalisert sklerodermi (6).

\section{Prognose}

- Normal forventet levetid.

- Stabilisering av sykdommen i løpet av 3-5 år hos de fleste.

- Vedvarende sykdomsaktivitet hyppigst ved linear sklerodermi (7).

- Mindre enn 1\% overgang til systemisk sklerose (5).

\section{Forskjell barn - voksne}

- Lokalisert sklerodermi er 10 ganger hyppigere enn systemisk sklerose hos barn.

- Lineær sklerodermi er meget sjeldent hos voksne.

\section{B. SYSTEMISK SKLEROSE}

\section{Klassifikasjon}

Det er vanlig å inndele undergrupper av systemisk sklerose på følgende måte (8):

\section{Diffust utbredt sklerose}

Fortykket hud på trunkus i tillegg til ansikt og proksimalt og distalt på ekstremiteter.

\section{Begrenset sklerose}

Fortykket hud begrenset til områder distalt for albuer og knær, men kan også innlemme ansikt og nakke. Synonym CREST: kalsinose, Raynaudfenomener, øsofagus affeksjon, sklerodaktyli, telangiektasi.

\section{Sklerodermi uten sklerodermi}

Ingen hudaffeksjon klinisk, men karakterisk indre organ affeksjon, karaffeksjon og immunologiske funn i serum.

\section{Overlappende}

Fyller kriterier for systemisk sklerose, men samtidig RA, SLE eller inflammatorisk muskelsykdom.

Omgivelseindusert sklerose

Udifferensiert bindevevssykdom/preskleroderma. Raynaud-fenomener med kliniske og/eller laboratoriefunn assosiert med systemisk sklerose: anticentromer antistoff, unormal kapilaroskopi av negler, fingerødemer eller ischemisk skade.

Bare ett tilfelle av sklerodermi uten sklerodermi er rapportert hos barn (9), ingen tilfeller av omgivelseindusert sklerose.

\section{Klassifikasjonskriterier / Diagnostiske kriterier}

ACR-klassifikasjonskriteriene (10) er de mest brukte hos voksne og tidligere hos barn og fungerer mye som diagnostiske kriterier. Disse er som følger:

\section{Major kriterieum}

Typisk sklerodermatøs hud som involverer hud proksimalt for MCP og MTP ledd (lokaliserte former for sklerodermi må utelukkes).

\section{Minor kriterium}

- Sklerodermatøs hud begrenset til fingre

- Digitale arr etter ischemi

- Bibasilær pulmonal fibrose som ikke skyldes primær lungesykdom

Sikker diagnose: 1 major +2 minor.

En multisenter, flernasjonal gruppe som representer PRES (Paediatric Rheumatology European Society), ACR (American College of Rheumatology) og EULAR (European League Against Rheumatism) har nå foreslått nye diagnostiske kriterier for diagnose av systemisk sklerose hos barn og unge under 16 år (11). Man krever at hovedkriteriet og minst 2 av 20 underkriterier er til stede:

Hovedkriterium (obligat) - Proksimal sklerose/indurasjon av hud

Underkriterier - to av de følgende 20 må oppfylles:

- Hud: Sklerodaktyli

- Kar: Raynaud-fenomener, negleseng kapillære forandringer eller digitale sår

- GI traktus: Dysfagi eller gastroøsofageal refluks

- Nyre: Renal krise eller nytilkommen arteriell hypertensjon

- Hjerte: Arytmi eller hjertesvikt

- Lunger: Tegn til lungefibrose, unormal diffusjonkapasitet i lunger mht. karbonmonoksid (DLCO) eller pulmonal hypertensjon

- Muskelskjelett: "Tendon friction ribs", artritt eller myositt

- Nevrologisk: Nevropati eller karpal tunnel syndrom

- Serologisk testing: Tilstedeværelse av ANA eller systemisk sklerose selektive antistoffer

\section{Insidens}

Insidens av juvenil systemisk sklerose er usikker. I USA er det rapportert insidens på 1-2/100.000 pr. år hos voksne (12). Det er beregnet at under $10 \%$ av alle pasienter utvikler sykdommen før 20 års alder, 1,5\% under 10 års alder (13-16). Barn er funnet kun å utgjøre $3 \%$ av alle tilfeller av systemisk sklerose i populasjonsstudier (14). Dette tilsier en årlig insidens hos barn på under $1 / 1.000 .000$ pr. år.

Det er rapportert at jenter får sykdommen 3 ganger hyppigere enn gutter $\mathrm{i}$ aldersgruppen over 8 år, mens det i yngre alder ikke er funnet sikker forskjell mellom kjønnene (17). 


\section{Prognose}

Mortalitet: I tre eldre artikler er det rapportert til sammen 12 dødsfall hos barn/unge mellom 4 og 16 år (13,18-19). Median alder for sykdomsdebut i disse rapporteringene var 10 år fordelt mellom 4 og 16 år. Median sykdomsvarighet frem til død var 24 måneder, fra 5 til 120 måneder. Dødsårsakene var følgende: Hjertesvikt 5, hjertesvikt og pulmonal hypertensjon 1, pulmonal hypertensjon 2, lungeemboli 1 , CNS affeksjon og hypertoni 1 , nyresvikt 1 , hjerneblødning som ledd i trombocytopeni 1.

Foeldvari et al. (20) har rapportert resultater fra en stor multisenterstudie fra Europa og Nord- og Søramerika. 122 av 135 var hvite kaukasier, 100 var jenter. Gjennomsnittlig alder ved sykdomsdebut var 8,8 år ( $\mathrm{SD} \pm 3,3$ år), og gjennomsnittlig oppfølgningstid siden diagnose ved follow-up var 5 år $(\mathrm{SD} \pm 3,3$ år). Ved follow-up var sykdommen aktiv og trengte medisinering hos 82 , aktiv sykdom uten medisinering hos 36 og remisjon hos 16 . 95\% av de levende pasientene var i full daglig aktivitet ved follow-up. Ett, to og 4 års overlevelse var henholdsvis 99, 97 og 95\%. Åtte pasienter var rapportert døde, 5 av hjertesvikt, en av nyresvikt, en av sepsis og en av ukjent årsak.

I 2006 ble det rapportert resultat fra 2 undersøkelser av større grupper barn med systemisk sklerose. I den ene undersøkelsen sammenlignes funn hos dem med debut både i barnealder og voksenalder.

Scapolini et al. (21) rapporterer resultater fra til sammen 2559 pasienter med symptomdebut fra og med 16 år og 111 (4\%) med symptomdebut før 16 år, tilsett i Pennsylvania, USA, i perioden 1960-2003. Voksne ble inndelt i yngre voksne (16-40 år) og eldre voksne ( $>40$ år). Kumulativ overlevelsesrate etter 5 , 10, 15 og 20 år var: symptomdebut < 16 år: 89\%, 80\%, $74 \%$ og $69 \%$, yngre voksne: $85 \%, 79 \%, 67 \%, 52 \%$, eldre voksne: $75 \%, 55 \%, 35 \%, 20 \%$. Det var til sammen 32 døde i barnegruppen, 17 med kjent relasjon til bindevevssykdommen. Man fant høyere prosentdel død av hjertesykdom hos dem med debut i barnealder enn både yngre og eldre voksne. Død av nyresykdom var imidlertid assosiert med økende alder ved sykdomsdebut. Dersom man vurderte barn med både symptomdebut og diagnose stillet før 16 år (62 av barna), var kumulativ overlevelsesrate etter 5, 10, 15 og 20 år: 91\%,88\%, 88\%, 84\%.

Martini et al. (22) rapporterer resultater fra 153 pasienter $i$ en stor multisenterundersøkelse fra 55 sentre fra Europa, Asia og Sør- og Nord-Amerika. "Outcome data" var tilgjengelig fra 127 pasienter. Av disse var 15 (11,8\%) døde. Ti døde av hjertesvikt hvorav to med pulmonal hypertensjon, 2 av nyresvikt hvorav en med pulmonal hypertensjon, 2 av respirasjonssvikt og 1 av sepsis. Alder for død var 5-15 år, gjennomsnitt 10,4 år. Tid fra første symptomer på sykdom til diagnose ble stilt var signifikant kortere hos de som døde, gjen- nomsnitt 8,8 måneder mot 23 måneder hos de som fortsatt var i live. 4 pasienter $(26,7 \%)$ døde første året etter diagnose, 11/15 innen 5 år.

I en undersøkelse hos voksne fra Sverige (23) rapporteres det om henholdsvis 5- og 10-års overlevelse på gjennomsnittlig $86 \%$ og $69 \%$ og med signifikant høyere dødelighet hos dem med diffus systemisk sklerose enn systemisk lokalisert sklerose. Det var også noe høyere dødelighet hos menn enn kvinner. Det ble beregnet 4,6 ganger økt risiko for død sammenlignet med den vanlige populasjonen.

Disse resultatene tyder på at utsiktene hos barn er generelt bedre enn hos voksne. Hos de barna som man ser en dødelig utgang på er imidlertid sykdommen ofte raskt utviklende. Tidlig affeksjon av indre organer er assosiert med dårlig prognose.

Man kan imidlertid også spekulere i om lavere rapportert mortalitet hos barn enn voksne delvis kan skylles mindre komorbiditet og at barn tolererer og kompenserer bedre påvirkning av sykdom og utvikler mildere bivirkninger av behandling enn voksne.

\section{KONKLUSJON}

\section{Lokalisert sklerodermi}

Dette er den hyppigste sklerodermiform hos barn. Insidensen er usikker, men trolig 5-10/100.000/år. Sykdommen inndeles i 5 undergrupper. Barnerevmatologer rapporterer at lineær sklerodermi er den hyppigste undergruppe, mens det fra hudavdeling er rapportert at plaque morfea er hyppigst, nærmest fulgt av lineær sklerodermi.

Ved lineær sklerodermi vil lesjonen ofte følge et dermatom i underekstremiteter. Det kan lede til hypoplasi av underhud, muskulatur og ben med muskelatrofi og nedsatt lengdevekst som følger. Man forventer at sykdommen stabiliserer seg i løpet av 3-5 år. Risiko for overgang til systemisk sklerose anses $<1 \%$. Man forventer normal livslengde.

\section{Systemisk sklerose}

Meget sjelden sykdom hos barn, insidens

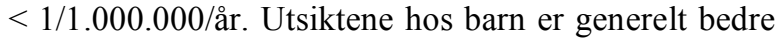
enn hos voksne. Hyppigste dødsårsak er rapportert å være hjertesvikt med eller uten pulmonal hypertensjon. Det er også rapportert dødsfall av nyresvikt, respirasjonssvikt, CNS-affeksjon og sepsis. Kumulativ overlevelse etter 5, 10, 15 og 20 år sykdommen er rapportert å være $89 \%, 80 \%, 74 \%$ og 69\%. For aldersgruppen $<16$ år er median alder for død rapportert til 10,4 år varierende mellom 5 og 15 år. Hos barn med dødelig utgang er sykdommen som regel raskt utviklende. Tidlig affeksjon av indre organer er assosiert med dårlig prognose. 


\section{REFERANSER}

1. Peterson LS, Nelson AM, Su WP. Classification of morphea (localized scleroderma). Mayo Clin Proc 1995; 70: $1068-76$.

2. Marzano AV, Menni S, Parodi A et al. Localized scleroderma in adults and children. Clinical and laboratory investigations on 239 cases. Eur J Dermatol 2003; 13: 171-6.

3. Zulian F, Athreya BH, Laxer R et al. Juvenile localized scleroderma: clinical and epidemiological features in 750 children. An international study. Rheumatology 2006; 45: 614-20.

4. Vancheeswaran R, Black CM, David J et al. Childhood-onset scleroderma: Is it different from adult-onset disease? Arthritis Rheum 1996; 39: 1041-9.

5. Zulian F, Vallongo C, Woo P et al. Localized scleroderma in childhood is not just a skin disease. Arthritis Rheum 2005; 52: 2873-81.

6. Woo P, David J, Vancheeswaran R et al. Is scleroderma the same disease in childhood. Arthritis Rheum 1992; 35: S137.

7. Peterson LS, Nelson AM, Su WP et al. The epidemiology of morphea (localized scleroderma) in Olmsted County 1960-1993. J Rheumatol 1997; 24: 73-80.

8. LeRoy EC, Black C, Fleischmajer R et al. Scleroderma (systemic sclerosis): classification, subsets and pathogenesis. J Rheumatol 1988; 15: 202-5.

9. Navon P, Halevi A, Brand A et al. Progressive systemic sclerosis sine scleroderma in a child presenting as nocturnal seizures and Raynaud's phenomenon. Acta Paediatr 1993; 82: 122-3.

10. Masi AT, Rodnan GP, Medsger TA Jr et al. Preliminary criteria for the classification of systemic sclerosis (scleroderma). Arthritis Rheum 1980; 23: 581-90.

11. Zulian F, Woo P, Athreya BH et al. The Pediatric Rheumatology European Society/American College of Rheumatology/European League against Rheumatism provisional classification criteria for juvenile systemic sclerosis. Arthritis Rheum 2007; 57: 203-12.

12. Lawrence RC, Helmick CG, Arnett FC et al. Estimates of the prevalence of arthritis and selected musculoskeletal disorders in the United States. Arthritis Rheum 1998; 41: 778-99.

13. Kornreich HK, King KK, Bernstein BH et al. Scleroderma in childhood. Arthritis Rheum 1977; 20 (2 Suppl): 343-50.

14. Medsger, TA Jr. Epidemiology of systemic sclerosis. Clin Dermatol 1994; 12: 207-16.

15. Uziel Y, Miller ML, Laxer RM. Scleroderma in children. Pediatr Clin North Am 1995; 42: 1171-1203.

16. Tuffanelli DL, Winkelmann RK. Systemic scleroderma. Arch Dermatol 1961; 84: 359-71.

17. Zulian F, Cassidy JT. The systemic sclerodermas and related disorders. In: Textbook of Pediatric Rheumatology. Cassidy JT, Petty RE, Laxer RM, Lindsley, CB (Eds), Elsevier Saunders, Philadelphia, 2005: 442.

18. Cassidy JT, Sullivan DB, Dabich L et al. Scleroderma in children. Arthritis Rheum 1977 20: 351-4.

19. Suarez-Almazor ME, Catoggio LJ, Maldonado-Cocco JA et al. Juvenile progressive systemic sclerosis: clinical and serologic findings. Arthritis Rheum 1985; 28: 699-702.

20. Foeldvari I, Zhavania M, Birdi N et al. Favourable outcome in 135 children with juvenile systemic sclerosis: results of a multi-national survey. Rheumatology 2000; 39: 556-9.

21. Scalapino K, Arkachaisri T, Lucas M et al. Childhood onset systemic sclerosis: classification, clinical and serologic features, and survival in comparison with adult onset disease. J Rheumatol 2006; 33: 1004-13.

22. Martini G, Foeldvari I, Russo R et al. Systemic sclerosis in childhood: clinical and immunologic features of 153 patients in an international database. Arthritis Rheum 2006; 54: 3971-8.

23. Hesselstrand R, Scheja A, Akesson A. Mortality and causes of death in a Swedish series of systemic sclerosis. Ann Rheum Dis 1998; 57: 682-6. 